\title{
Société Française d'Allergie Séance du 24 octobre 1964
}

La perméabilité bronchique à $\Gamma$ écoulement de $\Gamma$ air chez $\Gamma$ enfant sain et asthmatique

F. Geubelle et J. Senterre

Clinique des Maladies de Гenfance, Prof. A. Lambrechts, Université de Liège, Belgique

Les debits aériens au cours d'une expiration forcée ont été mesurés sur un trace spirographique chez un groupe non sélectionné d'enfants sains, ágés de 7 à 16 ans et d'enfants asthmatiques sans symptôme pulmonaire. La reproductibilité de ces valeurs est peu satisfaisante et la variation d'un jour à $\Gamma$ autre est loin d'etre négligeable. Ces debits sont d'autant plus élevés que Tenfant est grand; mais dans une population non sélectionnée, la dispersion des valeurs est large au point qu'il n'est pas possible de séparer un groupe d'enfants sains et un groupe d'asthmatiques sans symptôme, sur la base de ce critère.

120 Proceedings - Gesellschaftsberichte - Sociétés

Dans ce groupe de patients asthmatiques, la resistance pulmonaire totale à Pécoule-ment de $\Gamma$ air (mesurée à Гaide d'un pneumotachographe et d'un catheter æsophagien) peut être doublée ou quintuplée sans que les valeurs des debits expiratoires soient signi-ficativement diñ $\tilde{}^{7} / 8$ rentes sur les traces spirographiques. En pratique, la mesure de ces debits est rarement utile; en effet, il existe presque toujours des signes cliniques de dyspnée lorsque les debits expiratoires sont significativement diminués.

L'allergie au pollen d'ambrosia dans la region lyonnaise

R. TOURAINE, J. CORNILLON ET B. DE PoUMEYROL

Ambrosia artemisiaefolia (Common Ragweed) dont le role est extrêmement important dans la pollinose d'automne en Amérique du Nord est apparue et s'est développée, de façon considerable, depuís quelques années dans la region lyonnaise, en particulier a $\Gamma$ Est de Lyon, dans le Bas-Dauphiné.

Les auteurs ont pu observer récemment un certain nombre de cas de manifestations allergiques respiratoires, survenant en août et septembre, et semblant bien dues au pollen d'Ambrosia. II s'agit de troubles apparus depuis peu d'années et survenant surtout chez des sujets habitant dans les quartiers Est et la banlieue Est de Lyon. Leur frequence semble augmenter rapidement actuellement: 32 cas ont été observes depuis 1958, dont 15 pour la seule année 1964.

Recherches cliniques sur 300 cas d'allergie aux piqures d'hyménoptères

Halla Brown et H. S. Bernton The George Washington University School of Medecine, Washington, D.C.

Les auteurs ont étudié 300 malades dont les symptômes avaient été déclanchés par une piqure d'hyménoptère. - Ils analysent pour chaque malade Page (repartition iden-tique dans toutes les tranches d'áge, contrairement à d'autres statistiques), le sexe (mas-culin pour les $2 / 3$ ), le metier, les antecedents familiaux (59\% des cas) et personnels (48\%) d'allergie, la frequence de l'allergie concomitante à la pénicilline (11\% des cas), le nombre des piqures antérieures (11 en moyenne), la localisation de la piqure, le genre d'insecte responsable (abeille 22\%, guêpes et frelons 67\%)

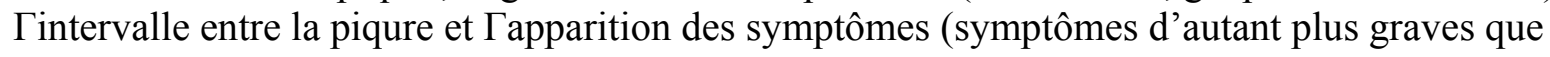


Гintervalle est plus bref), les divers symptômes ainsi que le mécanisme toxique ou allergique de certains d'entre eux.

Manifestations allergiques à la moutarde

Ed. Sidi, A. Gervais et M. P. Gervais

A propos de sept observations d'allergie grave de type anaphylactique à la moutarde, les auteurs décrivent $\Gamma$ étiologie, les signes cliniques et la physiopathologie de cette affection.

La sensibilisation à la moutarde noire résulte le plus souvent de Гapplication dans le jeune age de cataplasmes à la farine de moutarde.

Chez les sujets sensibles, la moutarde peut provoquer les symptômes par inhalation ou par contact, mais les troubles graves apparaissent surtout après Гingestion de traces de moutarde dans $\Gamma$ alimentation.

Proceedings - Gesellschaftsberichte - Sociétés

121

Les manifestations cliniques sont les suivantes: rhinite, toux, asthme, cedème de Quincke au niveau des lèvres, urticaire, vomissements, diarrhée et parfois collapsus cardio-vasculaire.

Le role probable de Гessence de moutarde, Гisosulfocyanate d'allyle (sénévol all·y-lique) est soulígné: cette substance est apte à se fixer sur les protéines et à constituer ainsi des antigènes vrais.

Beaucoup plus que la voie digestive, le contact cutané avec cette substance favorise probablement $\Gamma$ apparition de la sensibilisation anaphylactique.

Sur le plan pratique, il convient d'éviter, particulièrement chez les allergiques, toute application de farine de moutarde; dans la recherche d'une étiologie alimentaire en allergie, il convient de reconnaître le role des condiments parfois ignore pendant de longues périodes par le malade. Evaluation clinique d'un $\pi$ ouvel aerosol dans le traitement de $\Gamma$ asthme

S. W. Simon et W. H. Lipman Veterans Administration Center, Dayton, Ohio

Ce nouvel appareil à aerosols contient de l'isoproterenol qui provoque la broncho-dilatation par relachement des muscles lisses et vaso-constriction des muqueuses, du bromure de thonzonium qui a un effet mouillant ainsi qu'un certain pouvoir antibacté-rien et antifongique, de Гalcool éthylique et du propylène-glycol qui permettent la dissolution des deux premiers composants.

La comparaison des effets de cet aerosol avec deux autres aerosols du commerce et un placebo a été très favorable et $75 \%$ des malades ont obtenu un effet bon ou excellent, supérieur en intensité et en durée aux autres aerosols employes. Gontrastant avec Гopinion nettement exprimée des malades, les essais de mesure des fonctions pulmonaires n'ont pas permis d'objectiver l'amélioration ressentie.

Apports récents conçernant $\Gamma$ allergie a ГA.C.T.H.

J. Charpin, J. Aubert, C. Boutin et Ph. Ohresser

ont étudié la tolerance à deux nouveaux produits: une A.G.T.H. synthétique (tétracosapeptide Ciba) et une cortrophine extractive hautement purifiée (Endopancrine). Cette etude a été faite chez des sujets normaux et chez des asthmatiques ayant eu des accidents allergiques avec les anciennes preparations d'A.C.T.H., par tests cutanés, tests de Shelley et essais cliniques.

Chez 10 des 11 sujets allergiques à 1'A.C.T.H. extractive ancienne, l'A.C.T.H. synthétique a été parfaitement tolérée. La cortrophine purifiée, bien que plus allergi-sante que le tétracosapeptide, représente également un grand progrès sur les anciennes preparations. II apparait done que les accidents allergiques observes étaient, sinon toujours, tout au moins dans la grande majorité des cas, dus aux impuretés, l'allergie à l'hormone elle-même semblant tout à fait exceptionnelle. 
Ces preparations nouvelles vont permettre d'utiliser à nouveau chez l'asthmatiquedes hormones que la frequence des accidents de sensibilisation avait fait pratiquementabandonner. J. Sglafer, Paris

122

Proceedings - Gesellschaftsberichte - Sociétés

British Allergy Society

The Summer Meeting of the British Allergy Society was held at the Medical School, Birmingham University on Saturday 13th June, 1964. The speakers were Dr. R. M. Norris (Birmingham) on 'The effects of breathing inert dust on the distribution of ventilation and perfusion of the lungs', Dr. C. N. D. Cruickshank (Birmingham) on 'Allergy to fungi', Dr. K. R. Haye (Birmingham) on 'Basophile degranulation (Shelly technique) in atopic subjects', Dr. K. M. Citron (London) on 'Lung disease associated with eosinophilia', Dr. J. F. Soothill (Birmingham) on 'The presence in the serum of patients with glomerulo-nephritis of a qualitatively abnormal component of Complement (jSia)' and Dr. H. Morrow Brown on 'The importance of yeasts as allergens'.

Honorary Secretary: J. M. Smith, British Allergy Society, 21 Hagley Road West, Harborne, Birmingham 17.

The Effects of Breathing Inert Dust on the Distribution of Ventilation and Perfusion of the Lungs

R. M. Norris and J. M. Berhof

The Queen Elizabeth Hospital, Birmingham 15

Allergy to Fungi

C. N. D. Cruickshank M. R. C. Unit for Research on the Experimental Pathology of the Skin, The Medical School, University of Birmingham.

From deep cultures of Trichophyton mentographytes and Trichophyton rubrum, galacto-mannan peptides have been isolated and shown to be allergenic. These have the general structure of Dgalactose and D-mannose in the proportion of about 1 to 8 , and the protein is present to approximately $10 \%$. There is very close structural relationship between galactomannans from $\mathrm{T}$. mentagrophytes and from T. rubrum. In addition, they appear to be virtually completely crossreactive in guinea pigs and in humans. Clinical studies have been made with purified trichophytin and compared with the results obtained from commercial trichophytin. It appears that the incidence of immediate reactions obtained with the purified preparation is considerably reduced, while the incidence of delayed reactions is approximately the same.

Basophile Degranulation (Shelly Technique) in Atopic Subjects

K. R. Haye

M. R. C. Unit for Research of the Experimental Pathology of the Skin,

The Medical School, University of Birmingham.

The Shelley basophile degranulation technique and modifications of it have been examined in normal subjects, atopies and persons suffering from various hypersensitivities. The result of the direct test appear in atopic subjects to bear a close relationship with the clinical history and skin test results. The indirect test has proven less reliable, in that a higher proportion of the sera were toxic to rabbit basophils. In those tests in which serum did not produce this effect the correlation with the clinical history and the results of the direct test was unsatisfactory in that only about one half corresponded.

Proceedings - Gesellschaftsberichte - Sociétés

Lung Disease Associated with Eosinophilia 
K. M. Citron The Brompton Hospital, London.

The term pulmonary eosinophilia is applied to those conditions in which there occurs ill-defined pulmonary shadowing on the radiograph accompanied by blood eosinophilia. Cases of pulmonary eosinophilia vary widely in their clinical features and include mild transient disease similar to that described by Loeffler, recurrent disease, or progressive fatal disease with involvement of many organs of the body.

The following classification is suggested:

Parasitic infections: Ascaris, Schistosomes, filaria, lung fluke, hookworms, Strongy-loides, Echinococcus, Trichina, Entamoeba histolytica, whipworms, toxicara canis, liver fluke, beef tapeworm.

Tropical Pulmonary Eosinophilia: ? Filaria.

Fungal Injections: Aspergillus fumigatus, Coccidiomyiosis.

Inhalants: Pollen, spores (extrinsic asthma).

Medicaments: P. A. S. penicillin, sulphonamide, nitrofurantoin, sera.

Intrinsic Asthma.

Polyarteritis nodosa.

Unidentified Cause.

Between 1959 and 1963 forty-eight patients with pulmonary eosinophilia were investigated at Brompton Hospital, London. The causes found were allergic pulmonary aspergillosis in thirtyseven, tropical pulmonary eosinophilia in four, polyarteritis nodosa in two and the cause was obscure in five.

The Detection of the Altered Form of the Complement Component C'3A (Bic-BiA) 1/8 the Serum of Patients with Various Forms of Glomerulo-nephritis

\section{J. F. SOOTHILL}

Department of Experimental Pathology, The Medical School, University of Birmingham. It has been assumed that the low level of serum complement activity in the serum of patients with acute glomerulo-nephritis, is due to its being used up in an antigen-antibody reaction, though the evidence for this assumption is circumstantial. The observation by Muller-Eberhard and others that exposure of fresh human serum in vitro to an antigen-antibody reaction led to an alteration of the electrophoretic mobility of the complement component called $\mathrm{C}^{1 / 8 a}$ or $ß \backslash \mathrm{c}$ (to form the so-called $\beta \mathrm{i}$ ), provides a means of obtaining direct evidence for this assumption. Fresh plasma from patients with acute post-streptoccocal glomerulo-nephritis with low serum complement was found to contain the altered component, whereas controls were consistently negative using the same technique. Since this work was started, Lachmann has reported a similar phenomenon in Disseminated Lupus Erythematosus.

Other patients with acute nephritis syndrome with normal serum complement activity were also found to contain the abnormal constituent as was the serum of many patients with persistent proliferative glomerulo-nephritis. It was also found in the serum of patients with membranous glomerulo-nephritis, though at a lower concentration, providing the first direct evidence of an immunological basis for this disease process. This constituent has not been found in patients with nephrotic syndrome with minimal renal histological abnormality, or in nephrotic syndrome due to renal vein thrombosis.

124 Proceedings - Gesellschaftsberichte - Sociétés Allergy to Ingested and Airborne Yeasts as a Common Cause of Allergic Disorders H. Morrow Brown Derby Chest Clinic, 93 Green Lane, Derby. 
The observations of aerobiological factors in the spread of plant disease have clearly indicated that the air, particularly in the summer, contains large quantities of potential allergens. Close relationships of weather changes with symptoms, and ingestion of yeast tablets or beer followed by symptoms, suggested that yeasts might be important, but skin tests were valueless. Nasal provocation tests were found to produce many positive results by provoking symptoms, and results of this type of tests in nearly 600 patients were presented, showing that half of them were yeast sensitive. Data referring to de-sensitization by Depot emulsions of these allergens and subsequent demonstration of a negative nasal provocation test was presented.

An out-sized Bourdillon Slit Sampler to take automatic volumetric half hourly samples which had been devised by the author and used for making aerobiol $\&$ gt; gical observations on culturable allergens, was described and the intimate link-up between patient's symptoms and aerobiological changes was demonstrated.

I. It was pointed out that yeasts which have so far been used in provocation tests are not necessarily the correct ones and that a great deal of research requires to be done on air-borne yeasts. For example

certain patients had severe symptoms when in heavy rain but all attempts to identify these allergens had been unsuccessful. 